\title{
Hydrothermal Synthesis of New Compounds with the Pyrochlore Structure and Its Application to Nitric Oxide Abatement
}

\author{
Md. Hasan ZAHIR, Kazuyuki MATSUDA, Shingo KATAYAMA and Masanobu AWANO* \\ Synergy Ceramics Laboratory, FCRA, Shimo-Shidami, Moriyama-ku, Nagoya-shi 463-8687 \\ * Synergy Materials Research Center, National Institute of Advanced Industrial Science and Technology (AIST), \\ Shimo-Shidami, Moriyama-ku, Nagoya-shi 463-8687
}

\author{
パイロクロア構造を有する新化合物の水熱合成及びその $\mathrm{NO}_{x}$ 浄化特性 \\ Md. Hasan Zahir ·松田和幸 ·片山真吾 ·淡野正信* \\ ファインセラミックス技術研究組合シナジーセラミックス研究所，463-8687 名古屋市守山区下志段味穴ヶ洞 2268-1 \\ *産業技術総合研究所シナジーマテリアル研究センター，463-8687 名古屋市守山区下志段味穴ヶ洞 2268-1
}

\begin{abstract}
Several new compounds with a pyrochlore-type crystal structure have been synthesized by a low-temperature hydrothermal process under $\mathrm{N}_{2}$ atmosphere using a mixture of nitrate salts. The chemical compositions of the new pyrochlores are represented as (a) $\mathbf{Y}_{2} \mathrm{Sn}_{1.8} \mathrm{Cr}_{0.2} \mathrm{O}_{7}$, (b) $\mathbf{Y}_{1.8} \mathrm{Sm}_{0.2} \mathrm{Sn}_{1.8} \mathrm{Cr}_{0.2} \mathrm{O}_{7}$, (c) $\mathbf{Y}_{1.8} \mathrm{Ce}_{0.2} \mathrm{Sn}_{1.8}$ $\mathrm{Cr}_{0.2} \mathrm{O}_{7}$, (d) $\mathrm{Y}_{1.8} \mathrm{Eu}_{0.2} \mathrm{Sn}_{1.8} \mathrm{Cr}_{0.2} \mathrm{O}_{7}$, (e) $\mathrm{Y}_{2} \mathrm{Zr}_{1.8} \mathrm{Co}_{0.2} \mathrm{O}_{7}$, (f) $\mathrm{Ba}_{0.8} \mathrm{Y}_{1.2} \mathrm{Sn}_{1.8} \mathrm{Cr}_{0.2} \mathrm{O}_{7},(\mathrm{~g}) \mathrm{Ba}_{0.6} \mathbf{Y}_{1.2} \mathrm{Sm}_{0.2} \mathrm{Sn}_{1.8} \mathrm{Cr}_{0.2} \mathrm{O}_{7}$ and (h) $\mathrm{Ca}_{0.8} \mathrm{Sm}_{1.2} \mathrm{Sn}_{1.8} \mathrm{Ni}_{0.2} \mathrm{O}_{7}$. The Ba- and Ca-containing pyrochlores exhibited excellent spherical morphology with a pure pyrochlore phase structure and were composed of nanometer-sized particles. A- and B-sitedoped pyrochlores maintained a fully ordered crystal structure over a wide temperature range. The pyrochlore oxide powders were tested as catalysts for $\mathrm{NO}_{x}$ absorption and reduction by $\mathrm{CH}_{4}$. NO could be almost completely converted into $\mathrm{N}_{2}$ using hydrothermally derived pyrochlore oxide catalysts in the absence of oxygen at high temperatures. Rapid absorption of NO into alkali-substituted pyrochlores was effective for NO removal from the gas phase, absorption being significantly accelerated by the presence of oxygen.
\end{abstract}

[Received February 20, 2002; Accepted August 9, 2002]

Key-words : Hydrothermal, Pyrochlore oxide, Morphology, $N O$ reduction, $N O_{x}$ absorption

1. Introduction

Hydrothermal synthesis has been known to be a powerful method for the preparation of fine, high-purity and homogeneous powders of various single-component and multicomponent oxide powders. ${ }^{1)}$ Versatility of the pyrochlore materials is mainly associated with their unique crystal structure in which numerous functional substitutions at various lattice sites are possible, producing many compounds with different thermal, electrical, and catalytic properties. However, only a few investigators have attempted to synthesize pyrochlores with two or more different cations at the A site by the hydrothermal process. Several compounds with a pyrochlore structure of $\mathrm{AA}^{\prime} \mathrm{BB}^{\prime} \mathrm{O}_{7}(\mathrm{~A}=\mathrm{Ca}, \mathrm{Sr}, \mathrm{Ba}$, $\mathrm{Pb}, \mathrm{Cd} ; \mathrm{A}^{\prime}=\mathrm{La}, \mathrm{Pr}, \mathrm{Nd}$, Dy, Ho, Y; B=Ti, Zr, Hf, Sn; B' = $\mathrm{Nb}, \mathrm{Ta}$ ) have been synthesized by solid-phase reaction at high temperature. ${ }^{2)}$ Besides their high energy consumption, these solid-state reactions require a series of laborious heating cycles at high temperatures and repeated grinding of starting oxide components. Thus resulting powders show extensive agglomeration and compositional inhomogeneity.

Two main technologies have emerged recently: the direct reduction of $\mathrm{NO}$ by hydrocarbon on stream ${ }^{3)}$ or by a twostage operation whereby $\mathrm{NO}_{x}$ is trapped on a selective sorbent, and then reduced by a short fuel excursion. ${ }^{4}$ The key point in the latter strategy is the efficiency of $\mathrm{NO}_{x}$ absorption materials; they should adsorb (or absorb) a large quantity of $\mathrm{NO}_{x}$ in a high space velocity gas stream containing both $\mathrm{CO}_{2}$ and $\mathrm{H}_{2} \mathrm{O}$ in the temperature range of $25-350^{\circ} \mathrm{C}$. Belyaev et al.5) first reported the synthesis of mixed pyrochlore oxides with A- and B-site substitution, but the formation of the pyrochlore phase was poor in the case of $\mathrm{Ba}$ substitution at A sites. Recently, Hodjati et $a .^{6)}$ reported that if barium is incorporated in a well-defined structure presenting nanocrystallinity, $\mathrm{NO}_{x}$ storage is possible with high absorption/ desorption capacities. In the literature, numerous authors have claimed that on perovskites, namely, $\mathrm{LaBO}_{3}(\mathrm{~B}=\mathrm{Cr}$, $\mathrm{Mn}, \mathrm{Rh}), \mathrm{NO}$ interacts directly with the surface to form mono or dinitrosyl species or various forms of nitrates. ${ }^{7)}$ If this perovskite is doped with potassium $\left(\mathrm{La}_{0.8} \mathrm{~K}_{0.2}\right) \mathrm{MnO}_{3}$, molecular and dissociative adsorption of $\mathrm{NO}$ is observed. ${ }^{8)}$ Alternatively, if barium is incorporated as the cation at the A-site in the pyrochlore $\left(\mathrm{A}_{2} \mathrm{~B}_{2} \mathrm{O}_{7}\right)$, then because of its basicity, one might expect the formation of carbonates and nitrates, particularly in the presence of oxygen.

However, yttrium oxide has been examined as a bulk ceramic for high-temperature applications because of its high melting point, phase stability and low thermal expansion. ${ }^{9)}$ Moreover, due to the basic nature of yttrium oxide, it has more recently been found to be an effective catalyst for methane dimerization ${ }^{10}$ ) and the selective catalytic reduction of nitrogen oxide. ${ }^{11)}$ Stannate pyrochlores have attracted much interest for their high efficiency of oxidative coupling of methane, and these materials are also emerging as good catalysts for reactions such as NO reduction. ${ }^{12)}$ This is an important field due to the increasing demands for environment-related high-temperature catalytic applications such as the cleansing of automobile exhaust gas.

The objective of this work was to synthesize $\mathrm{Y}_{2} \mathrm{Sn}_{2} \mathrm{O}_{7^{-}}$ type pyrochlore compounds with $\mathrm{A}$ - and $\mathrm{B}$-site substitution and also double substitution in the A site, by a hydrothermal method. These stannate pyrochlores produced were tested for $\mathrm{NO}$ reduction by $\mathrm{CH}_{4}$, and selective removal of $\mathrm{NO}$ over $\mathrm{Ba}-$ and $\mathrm{Ca}$-containing pyrochlores was also investigated.

\section{Experimental procedure}

2.1 Synthesis of pyrochlore oxide powders

The precursors for hydrothermal synthesis of $\mathrm{Y}_{2} \mathrm{Sn}_{2} \mathrm{O}_{7}$ were prepared by coprecipitation from metal salt solutions. All chemicals used in this study were of reagent grade sup- 
plied from Wako Pure Chemical Industries. Appropriate quantities of $\mathrm{SnCl}_{4} \cdot 5 \mathrm{H}_{2} \mathrm{O}$ (Wako Pure Chemical Industries Ltd.), $\mathrm{Ce}\left(\mathrm{NO}_{3}\right)_{3} \cdot 6 \mathrm{H}_{2} \mathrm{O}$ (Wako Pure Chemical Industries Ltd.), $\mathrm{Cr}\left(\mathrm{NO}_{3}\right)_{3} \cdot 9 \mathrm{H}_{2} \mathrm{O}$ (Wako Pure Chemical Industries Ltd.), and $\mathrm{Mn}\left(\mathrm{NO}_{3}\right)_{2} \cdot 6 \mathrm{H}_{2} \mathrm{O}$ (Wako Pure Chemical Industries Ltd.) were dissolved in deionized water. Amorphous complex gels were precipitated by addition of $\mathrm{NH}_{4} \mathrm{OH}$ at $\mathrm{pH}$ $\sim 9$ because the tin hydrous gel becomes soluble above $\mathrm{pH}$ 10 . Then the solution was vigorously stirred for $24 \mathrm{~h}$. The coprecipitated gels were then repeatedly washed and redispersed in deionized water before hydrothermal reaction.

To determine synthesis conditions for producing pure pyrochlore phase, the $\mathrm{pH}$ of the washed precursor suspension was adjusted to the $\mathrm{pH}$ ranging from 7 to 11 by $\mathrm{NH}_{4} \mathrm{OH}$. The $\mathrm{pH}$-adjusted feedstock was placed in a Teflon bottle with an inner volume of $25 \mathrm{~cm}^{3}$ held in a stainlesssteel vessel followed by flushing with $\mathrm{N}_{2}$. After the vessel was sealed, hydrothermal reactions were performed at temperatures ranging from 110 to $190^{\circ} \mathrm{C}$ for $40 \mathrm{~h}$ using a $500-\mathrm{ml}-$ capacity autoclave with a magnetically driven stirrer (Model TPR-1, Taiatsu Techno). After reaction, the resulting powders were repeatedly washed by centrifugation and decantation with deionized water to remove undesirable anions such as $\mathrm{Cl}^{-}$and $\mathrm{NO}_{3}^{-}$followed by drying in an oven for $24 \mathrm{~h}$ at $120^{\circ} \mathrm{C}$.

\subsection{Characterization}

The crystalline phases were identified by X-ray diffractometry (XRD; Phillips APD 1700) using $\mathrm{Cu} \mathrm{K} \alpha$ radiation at $40 \mathrm{kV}$ and $40 \mathrm{~mA}$ with a monochromator over a $2 \theta$ range of $10-70^{\circ}$ at a scan rate of $2^{\circ} / \mathrm{min}$. The absorption state of $\mathrm{NO}_{x}$ was recorded as $\mathrm{KBr}$ pellets by Fourier transform infrared spectrometer (FT-IR; Shimadzu, Model 8200D). Morphology of the product particles was examined by scanning electron microscopy (SEM; JEOL JSM6330F) with an energydispersive X-ray (EDX) analyser (JEOL, JED-2001), while elemental distribution was investigated by selected-area EDX microanalyses with area sizes varying from $10 \mathrm{~nm}$ to 4 micrometers. EDX analysis confirms the presence of substitute elements. Particle size and surface area of the powders were also determined by a laser diffraction method (Nikkiso, Microtrac HRA 9320-X100/UPA 9340) and Brunauer-Emmett-Teller (B.E.T.) nitrogen adsorption technique (Coulter, Omnisorp 360), respectively. The powder density value was obtained using Ultrapycnometer 1000 Version 2.12

\subsection{Evaluation of $\mathrm{NO}_{x}$ removal abilities}

The catalytic tests were carried out in the steady-stateflow mode. Sample powders of $200 \mathrm{mg}$ were placed between quartz wool plugs in the reactor. The reactant gas mixture consisted of $0.1 \% \mathrm{NO}$, and $0.2 \% \mathrm{CH}_{4}$ balanced by $\mathrm{He}$ at a space velocity (SV) of $20000 \mathrm{~h}^{-1}$ was passed through the catalyst for NO reduction. For NO absorption/desorption experiments, a typical reactant blend of $800 \mathrm{ppm} \mathrm{NO,} \mathrm{10 \%}$ $\mathrm{O}_{2}+\mathrm{He}$ balance was passed through the catalyst while the temperature was linearly increased or decreased in the temperature range of $100-650^{\circ} \mathrm{C}$ with $1 \mathrm{~h}$ isothermal steps at any selected temperature during which the effluent gas was analysed. The flow rate of each reactant gas was controlled by a mass flow controller (STEC Inc.). The flow of each gas was fixed and held constant with a 4-channel electronic mass-flow controller (UCAR Instruments, MFB-21-1). A temperature controller (Leeds \& Northrup Instruments, Electromax V Plus) was used both for increasing the furnace temperature at linear heating rates $(10 \mathrm{~K} / \mathrm{min})$ and for keeping it constant at any selected value. Before the catalytic reaction, the catalysts were pretreated in air at $800^{\circ} \mathrm{C}$ for $2 \mathrm{~h}$. The total flow rate was $50 \mathrm{~cm}^{3} \cdot \mathrm{min}^{-1}$ over $0.2 \mathrm{~g}$ of catalyst $\left(\mathrm{W} / \mathrm{F}=0.24 \mathrm{~g} \cdot \mathrm{s} \cdot \mathrm{cm}^{-3}\right)$. NO conversion to $\mathrm{N}_{2}$ was evaluated using:

$\mathrm{NO}$ conversion to $\mathrm{N}_{2}(\%)=\left\{2\left[\mathrm{~N}_{2}\right] /[\mathrm{NO}]\right.$ in $\} \times 100$,

where $[\mathrm{NO}]^{\text {in }}$ is the inlet $\mathrm{NO}$ concentration and $\left[\mathrm{N}_{2}\right]$ is the concentration of $\mathrm{N}_{2}$ in the reactor effluent gas. Decomposition of the nitric oxide and total $\mathrm{NO}_{x}$ in the reactor effluent was detected using a chemiluminescent $\mathrm{NO}-\mathrm{NO}_{x}$ gas analyzer (Best Instruments, BCL-100 uH, BCU-100 uH). All other reactants were analyzed by on-line gas chromatography (Chrompack Micro-GC CP-2002). Blank experiments carried out by flowing the reactant streams over an empty reactor showed that no $\mathrm{NO}_{x}$ conversion occurred without catalyst.

\section{Results and discussion}

3.1 Synthesis of pyrochlore powders by hydrothermal method

Various synthesis processes of multicomponent powders with controlled morphology, size, and size distribution, against the different chemical reactivities between starting chemicals, have been reported. ${ }^{13), 14)}$ The reported processes, however, require complex steps and/or low concentrations of the starting chemicals. ${ }^{15)}$ On the other hand, the hydrothermal process is known to be a method for the preparation of fine, high-purity, and homogeneous oxide powders. ${ }^{1)}$ Crystalline powders form as a result of the interaction between the precursor and solution phases in hydrothermal synthesis. The $\mathrm{pH}$ of the solution mainly determines the chemical nature and its reaction of the solution species under a given thermodynamic condition. Therefore, the $\mathrm{pH}$ is a key variable in determining the phase composition of $\mathrm{Y}_{2} \mathrm{Sn}_{2} \mathrm{O}_{7}$ in the present study, similar to other hydrothermally derived powders such as $\mathrm{PbTiO}_{3}, \mathrm{PZT}$, $\mathrm{BaTiO}_{3}, \mathrm{TiO}_{2}$, and $\mathrm{ZrO}_{2}{ }^{16}$ ) Below the critical concentration for precipitation, the reaction product was amorphous with a minor phase of $\mathrm{SnO}_{2}$. At $\mathrm{pH} 7$, the reaction product was again mainly amorphous with a minor phase of $\mathrm{SnO}_{2}$. The amorphous gel started to crystallize into $\mathrm{Y}_{2} \mathrm{Sn}_{1.8} \mathrm{Cr}_{0.2} \mathrm{O}_{7}$ at $\mathrm{pH} 8$. However, the crystallization process was sluggish, so that a mixture of poorly crystallized $\mathrm{Y}_{2} \mathrm{Sn}_{2} \mathrm{O}_{7}$ and the minor phases $\left(\mathrm{SnO}_{2}\right.$ and $\left.\mathrm{YCO}_{3} \mathrm{OH}\right)$ was detected. An increase in the $\mathrm{pH}$ facilitates crystallization of $\mathrm{Y}_{2} \mathrm{Sn}_{2} \mathrm{O}_{7}$. The phase composition of the product obtained at $\mathrm{pH} 9$ was identical to that obtained at $\mathrm{pH} 8$, but crystallinity was higher. Crystalline $\mathrm{Y}_{2} \mathrm{Sn}_{2} \mathrm{O}_{7}$ with phase-pure pyrochlore structure was formed only when the $\mathrm{pH}$ of the hydrothermal reaction medium was above $\mathrm{pH} 10$. At $\mathrm{pH} 11$ or higher, highlycrystalline $\mathrm{Y}_{2} \mathrm{Sn}_{2} \mathrm{O}_{7}$ was produced in less than $40 \mathrm{~h}$.

To determine the lowest synthesis temperature, the precursors prepared at $\mathrm{pH} 10.3$ were hydrothermally treated for $40 \mathrm{~h}$ at different temperatures ranging from 110 to $190^{\circ} \mathrm{C}$. The reaction product at $110^{\circ} \mathrm{C}$ was amorphous, whereas crystalline $\mathrm{Y}_{2} \mathrm{Sn}_{2} \mathrm{O}_{7}$ was obtained at $160^{\circ} \mathrm{C}$ with a minor amount of $\mathrm{SnO}_{2}$, as shown in Fig. 1. The impurity phase began to disappear above $160^{\circ} \mathrm{C}$, and phase-pure pyrochlore $\mathrm{Y}_{2} \mathrm{Sn}_{2} \mathrm{O}_{7}$ was formed at $190^{\circ} \mathrm{C}$. Recently, in our laboratory, well-defined $\mathrm{La}_{2} \mathrm{Sn}_{2} \mathrm{O}_{7}$ with a phase-pure pyrochlore structure has been synthesized by a hydrothermal process at temperatures as low as $200^{\circ} \mathrm{C}$. 17 )

The X-ray diffraction patterns of the hydrothermally synthesized powders are shown in Fig. 2. X-ray powder measurements did not show the presence of any material other than the desired pyrochlore phases, except in the cases of $\mathrm{Y}_{2} \mathrm{Zr}_{1.8} \mathrm{Co}_{0.2} \mathrm{O}_{7}$, which had the $\mathrm{YZrO}_{3}$ phase with a small portions of cubic $\mathrm{ZrO}_{2}$ and a trace amount of $\mathrm{SnO}_{2}$ was detected for the $\mathrm{Y}_{1.8} \mathrm{Eu}_{0.2} \mathrm{Sn}_{1.8} \mathrm{Cr}_{0.2} \mathrm{O}_{7}$ compound.

The effect of the calcination temperature was investigated based on a phase analysis by X-ray diffraction, as shown in Figs. 3(A) and (B). It has been reported that the struc- 


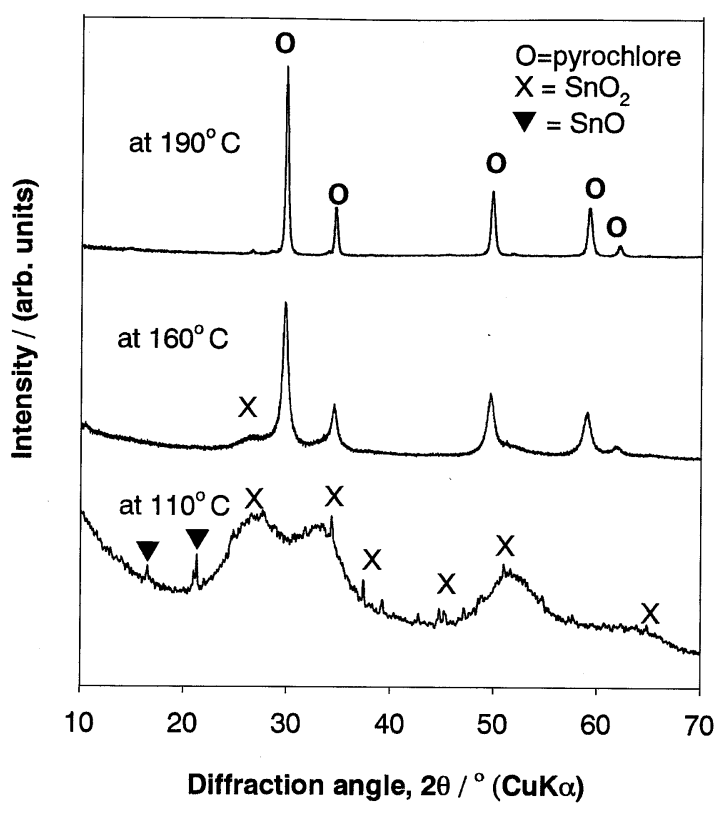

Fig. 1. XRD patterns of the product prepared as a function of synthesis temperature in solution with $\mathrm{pH} 10.30$ reacted for $40 \mathrm{~h}$.

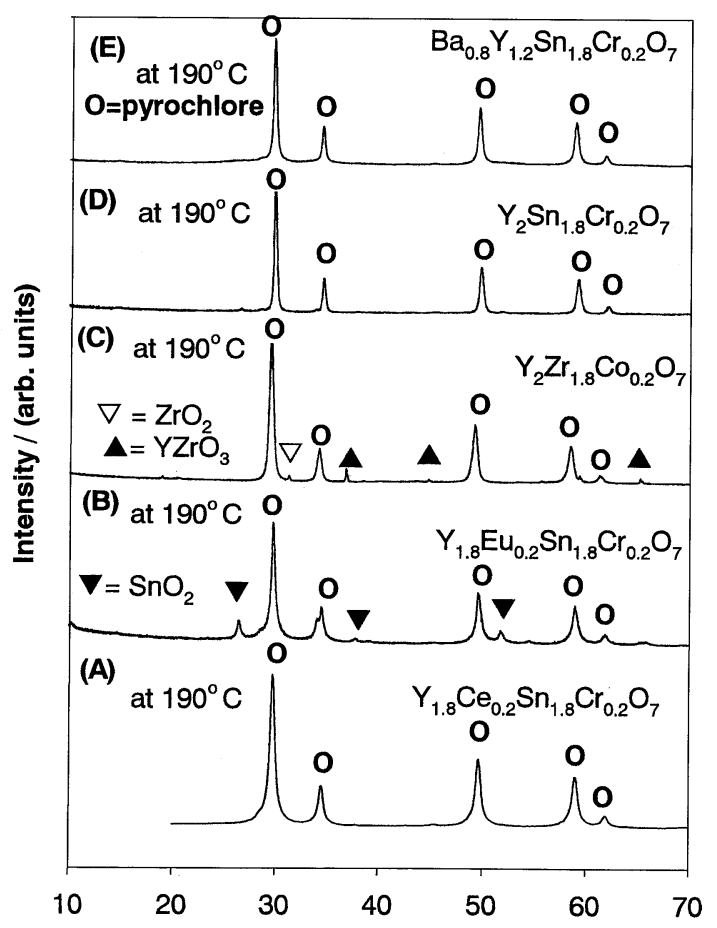

Diffraction angle, $2 \theta /{ }^{\circ}$ (CuK $\left.\alpha\right)$

Fig. 2. X-ray diffraction pattern of several hydrothermally derived pyrochlore oxide powders with A- and B-site substitutions.

ture of $\mathrm{Y}_{2} \mathrm{Sn}_{2} \mathrm{O}_{7}$ remained consistently fully ordered over a temperature range of $25-1000^{\circ} \mathrm{C} .{ }^{18)}$ This phenomenon was also observed even after A- and B-site substitutions in this present study. However, Fig. 3(A) shows that as the calcination temperature increased, the diffraction lines grew and indicated the formation of crystalline $\mathrm{SnO}_{2}$ phase from $800^{\circ} \mathrm{C}$, and were sharpened with increasing temperature
A

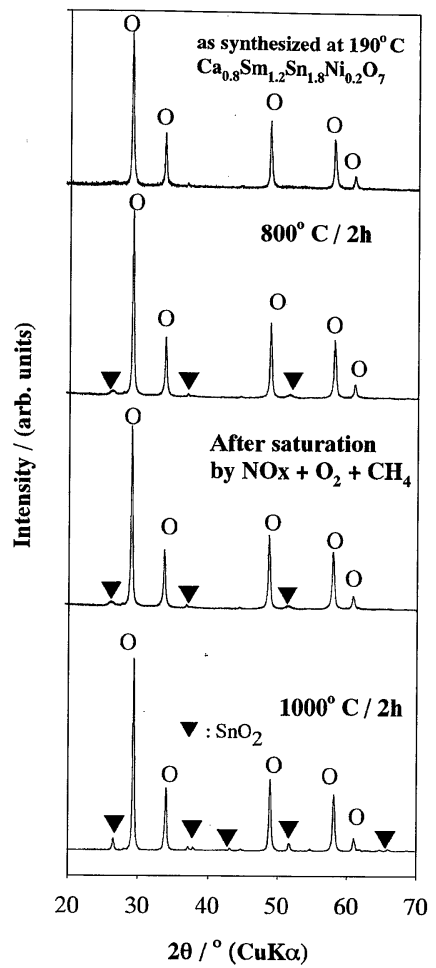

B

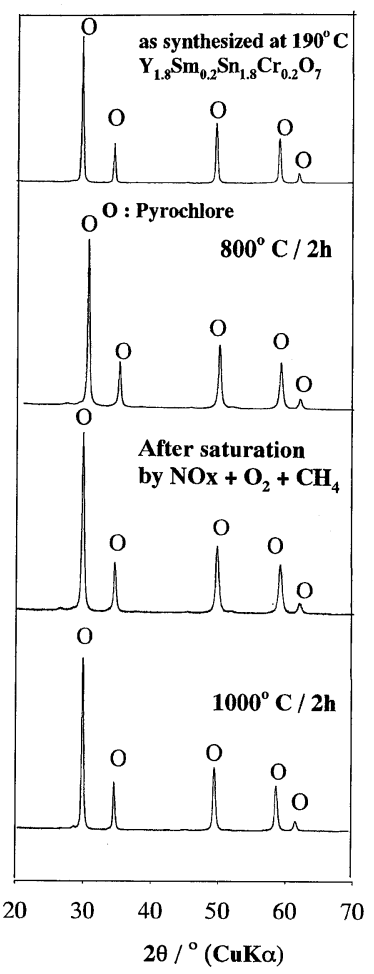

Fig. 3. X-ray diffraction pattern of (A) $\mathrm{Ca}_{0.8} \mathrm{Sm}_{1.2} \mathrm{Sn}_{1.8} \mathrm{Ni}_{0.2} \mathrm{O}_{7}$ and (B) $\mathrm{Y}_{1.8} \mathrm{Sm}_{0.2} \mathrm{Sn}_{1.8} \mathrm{Cr}_{0.2} \mathrm{O}_{7}$ pyrochlore showing phase stability behavior as a function of temperature.

only for the Ca-containing $\mathrm{Ca}_{0.8} \mathrm{Sm}_{1.2} \mathrm{Sn}_{1.8} \mathrm{Ni}_{0.2} \mathrm{O}_{7}$ compound. The crystallite size and the BET surface areas of synthesized powders are presented in Table 1.

SEM observation revealed that the synthesized particles have fairly spherical shapes with rough surfaces, as presented in Fig. 4. The sizes of the primary particulates were in the range of tens of nanometers. This indicates that the spherical shapes of powders are retained during hydrothermal treatment. In addition, the sources of A-site ions (barium or calcium) are incorporated and they are crystallized into the pyrochlore phases under hydrothermal conditions. $\mathrm{Ba}$ - and Ca-containing pyrochlore powders showed spherical shape, while all other powders have nearly spherical shape, as shown in Fig. 4. The particle size also has a relatively narrow distribution. Figure 5 shows transmission electron micrographs of the pyrochlore powders synthesized by hydrothermal treatment. The powders consisted of spherical secondary particles composed of small primary particulates.

3.2 $\mathrm{NO}_{x}$ reduction activity of single- or double-substituted stannate pyrochlore powders

Figure 6 shows the temperature dependence of the NO reduction activity of stannate pyrochlores: (a) $\mathrm{Y}_{2} \mathrm{Sn}_{1.8}$ $\mathrm{Cr}_{0.2} \mathrm{O}_{7}$, (b) $\mathrm{Y}_{1.8} \mathrm{Sm}_{0.2} \mathrm{Sn}_{1.8} \mathrm{Cr}_{0.2} \mathrm{O}_{7}$, (c) $\mathrm{Y}_{1.8} \mathrm{Ce}_{0.2} \mathrm{Sn}_{1.8} \mathrm{Cr}_{0.2} \mathrm{O}_{7}$, (d) $\mathrm{Y}_{1.8} \mathrm{Eu}_{0.2} \mathrm{Sn}_{1.8} \mathrm{Cr}_{0.2} \mathrm{O}_{7}$, (e) $\mathrm{Y}_{2} \mathrm{Zr}_{1.8} \mathrm{Co}_{0.2} \mathrm{O}_{7}$, (f) $\mathrm{Ba}_{0.8} \mathrm{Y}_{1.2}$ $\mathrm{Sn}_{1.8} \mathrm{Cr}_{0.2} \mathrm{O}_{7}$, (g) $\mathrm{Ba}_{0.6} \mathrm{Y}_{1.2} \mathrm{Sm}_{0.2} \mathrm{Sn}_{1.8} \mathrm{Cr}_{0.2} \mathrm{O}_{7}$ and (h) $\mathrm{Ca}_{0.8}$ $\mathrm{Sm}_{1.2} \mathrm{Sn}_{1.8} \mathrm{Ni}_{0.2} \mathrm{O}_{7}$. The activity appeared for all tested samples above $500^{\circ} \mathrm{C}$ and increased monotonically with increasing temperature in the presence of $\mathrm{CH}_{4}$. $\mathrm{NO}$ reduction activity was observed from a lower temperature region for $\mathrm{Ce}$ doped $\mathrm{Y}_{1.8} \mathrm{Ce}_{0.2} \mathrm{Sn}_{1.8} \mathrm{Cr}_{0.2} \mathrm{O}_{7}$ catalyst. However, when only $2 \% \quad \mathrm{O}_{2}$ was present, the NO conversion rate decreased drastically to $3 \%-4 \%$ of that achieved with $\mathrm{CH}_{4}$. Teraoka et al. ${ }^{19)}$ also observed excellent catalytic activity over tran- 
Table 1. Particle Characteristics of a Number of Hydrothermally Derived Oxide Pyrochlore Stannates of the Type $\mathrm{Y}_{2} \mathrm{Sn}_{2} \mathrm{O}_{7}$ with Aand B-Site Substitutions

\begin{tabular}{ll}
\hline & \multicolumn{1}{c}{ Reaction Conditions } \\
\cline { 2 - 2 } Concentration & $0.1 \mathrm{M}$ \\
Stirring Speed & $500 \mathrm{rpm}$ \\
Reaction Time & $40 \mathrm{~h}$ \\
Temperature & $190^{\circ} \mathrm{C}$ at $\mathrm{pH} 10.30$
\end{tabular}

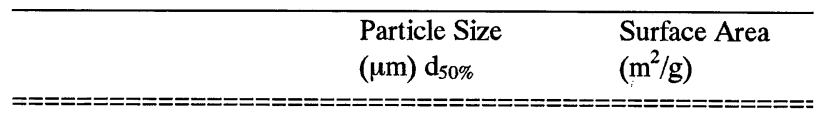

$\mathrm{Y}_{2} \mathrm{Sn}_{1.8} \mathrm{Cr}_{0.2} \mathrm{O}_{7}$
$800^{\circ} \mathrm{C}$

$\mathrm{Y}_{1.8} \mathrm{Sm}_{0.2} \mathrm{Sn}_{1.8} \mathrm{Cr}_{0.2} \mathrm{O}_{7}$

$800^{\circ} \mathrm{C}$

1.0111

40.12

$\mathrm{Y}_{1.8} \mathrm{Ce}_{0.2} \mathrm{Sn}_{1.8} \mathrm{Cr}_{0.2} \mathrm{O}_{7}$

$800^{\circ} \mathrm{C}$

1.2255

43.28

$\mathrm{Y}_{1.8} \mathrm{Eu}_{0.2} \mathrm{Sn}_{1.8} \mathrm{Cr}_{0.2} \mathrm{O}_{7}$

$800^{\circ} \mathrm{C}$

$\mathrm{Y}_{2} \mathrm{Zr}_{1 \cdot 8} \mathrm{Co}_{0.2} \mathrm{O}_{7}$

$800^{\circ} \mathrm{C}$

2.1345

26.36

$\mathrm{Ba}_{0.6} \mathrm{Y}_{1.2} \mathrm{Sm}_{0.2} \mathrm{Sn}_{1.8} \mathrm{Cr}_{0.2} \mathrm{O}_{7}$

$475^{\circ} \mathrm{C} / 4 \mathrm{~h}$

$800^{\circ} \mathrm{C} / 1 \mathrm{~h}$

1.1456

2.1450

61.59

22.44

$\mathrm{Ba}_{0.8} \mathrm{Y}_{1.2} \mathrm{Sn}_{1.8} \mathrm{Cr}_{0.2} \mathrm{O}_{7}$

$475^{\circ} \mathrm{C} / 4 \mathrm{~h}$

1.3456

$800^{\circ} \mathrm{C} / 1 \mathrm{~h}$

2.3441

58.59

23.94

$\mathrm{Ca}_{0.8} \mathrm{Sm}_{1.2} \mathrm{Sn}_{1.8} \mathrm{Ni}_{0.2} \mathrm{O}_{7}$

$475^{\circ} \mathrm{C} / 4 \mathrm{~h}$

$800^{\circ} \mathrm{C} / 1 \mathrm{~h}$

1.5456

2.38441

42.87

17.94

sition-metal-substituted $\mathrm{La}_{2} \mathrm{Sn}_{2} \mathrm{O}_{7}$ pyrochlore under non-oxidizing atmosphere.

$\mathrm{NO}$ reduction by $\mathrm{CH}_{4}$ is considered to be a key reaction for $\mathrm{NO}_{x}$ removal from automotive exhaust. A number of authors have examined the mechanism of this reaction and different reaction pathways have been suggested. However, methane can react not only with nitric oxide but also with $\mathrm{O}_{2}$ via combustion as follows:

$$
\begin{aligned}
& 4 \mathrm{NO}+\mathrm{CH}_{4} \rightarrow 2 \mathrm{~N}_{2}+\mathrm{CO}_{2}+2 \mathrm{H}_{2} \mathrm{O} \\
& 2 \mathrm{NO}+\mathrm{O}_{2}+\mathrm{CH}_{4} \rightarrow \mathrm{N}_{2}+\mathrm{CO}_{2}+2 \mathrm{H}_{2} \mathrm{O},
\end{aligned}
$$

and

$$
2 \mathrm{O}_{2}+\mathrm{CH}_{4} \rightarrow \mathrm{CO}_{2}+2 \mathrm{H}_{2} \mathrm{O}
$$

Besides the nitric oxide reduction reactions (Eqs. 1 and 2), $\mathrm{CH}_{4}$ also reacts with oxygen (Eq. 3). Since NO reduction was carried out in the absence of oxygen, Eq. 1 prevails in this study.

A promotional effect of $\mathrm{CH}_{4}$ on $\mathrm{NO}$ conversion to $\mathrm{N}_{2}$ might be expected since $\mathrm{CH}_{4}$ can facilitate the removal of surface oxygen via the reduction of nitrogen oxide species. Indeed, $\mathrm{CO}_{2}$ was observed instead of $\mathrm{O}_{2}$ in the presence of $\mathrm{CH}_{4}$, indicating an interaction between $\mathrm{CH}_{4}$ and surface oxygen.

3.3 Sorption/desorption of NO during heating

Recently, it has been reported that if barium is incorporat- ed in a well-defined structure presenting nanocrystallinity, $\mathrm{NO}_{x}$ storage is possible with high absorption/desorption capacities. ${ }^{6), 20), 21)}$ The sorption-desorption characteristics of $\mathrm{NO}_{x}$ were evaluated by heating the sample at a constant rate in the presence of a NO- $\mathrm{O}_{2}$ mixture, as shown in Fig. 7. The broken line in the figure is the NO concentration in the feed gas, i.e., the concentration levels below and above this line indicate $\mathrm{NO}$ uptake and $\mathrm{NO}_{x}$ desorption, respectively. The concentration of $\mathrm{NO}_{x}$ was measured, using a $\mathrm{NO}_{x}$ meter, as the sum of $\mathrm{NO}$ and $\mathrm{NO}_{2}$ concentrations. The curves for both $\mathrm{Ba}_{0.6} \mathrm{Y}_{1.2} \mathrm{Sm}_{0.2} \mathrm{Sn}_{1.8} \mathrm{Cr}_{0.2} \mathrm{O}_{7}$ and $\mathrm{Ca}_{0.8} \mathrm{Sm}_{1.2}$ $\mathrm{Sn}_{1.8} \mathrm{Ni}_{0.2} \mathrm{O}_{7}$ oxides initially showed complete removal of $\mathrm{NO}$ in the low-temperature region. Then, $\mathrm{NO}_{x}$ desorption started at 250 and $400^{\circ} \mathrm{C}$ for $\mathrm{Ba}_{0.6} \mathrm{Y}_{1.2} \mathrm{Sm}_{0.2} \mathrm{Sn}_{1.8} \mathrm{Cr}_{0.2} \mathrm{O}_{7}$ and $\mathrm{Ca}_{0.8} \mathrm{Sm}_{1.2} \mathrm{Sn}_{1.8} \mathrm{Ni}_{0.2} \mathrm{O}_{7}$ oxides, respectively, and reached maxima at 310 and $460^{\circ} \mathrm{C}$. The absorption behavior of $\mathrm{Ba}_{0.6} \mathrm{Y}_{1.2} \mathrm{Sm}_{0.2} \mathrm{Sn}_{1.8} \mathrm{Cr}_{0.2} \mathrm{O}_{7}$ was basically the same as that of $\mathrm{Ba}_{0.8} \mathrm{Y}_{1.2} \mathrm{Sn}_{1.8} \mathrm{Cr}_{0.2} \mathrm{O}_{7}$, except for a difference in the overall amount of absorption. At elevated temperatures, the desorption curve approached the initial concentration level as absorption/desorption proceeded. In the presence of gaseous $\mathrm{O}_{2}$, absorption of $\mathrm{NO}$ by this reaction was enhanced. The enhancement of $\mathrm{NO}$ removal by $\mathrm{O}_{2}$ strongly suggests that the absorption proceeds via oxidation of NO. The NO removal is, therefore, attributed to catalytic oxidation and subsequent absorption of NO, where nitrate-related compounds are probably formed in the oxides.

The reversibility of the absorption and desorption of the $\mathrm{Ba}_{0.6} \mathrm{Y}_{1.2} \mathrm{Sm}_{0.2} \mathrm{Sn}_{1.8} \mathrm{Cr}_{0.2} \mathrm{O}_{7}$ oxide was tested by repeating the absorption of $\mathrm{NO}$ at $200^{\circ} \mathrm{C}$ and desorption at $450^{\circ} \mathrm{C}$ in $\mathrm{He}$. The phenomenon of absorption/desorption is perfectly reproducible and can be repeated many times without deactivation. Although the absorption capacity of the first absorption experiment after a heat treatment at $475^{\circ} \mathrm{C}$ was the highest, it then decreased and was almost constant from the 2nd cycle, indicating that absorption and thermal desorption was almost reversible. The amount of absorption at the fifth absorption step decreased to approximately $85 \%$ of that at the first step. This decrease may have resulted from a decrease in the surface area, or grain growth of tin oxide and substituted transition metal oxides.

As mentioned above, the high absorption rate and capacity are generally attained using more basic components. The alkaline earth is effective in this respect. However, the use of the bulk alkaline or rare earth compounds implies degradation due to the formation of stable carbonate in the presence of $\mathrm{CO}_{2} \cdot{ }^{22)}$ In this respect, reversibility of $\mathrm{Ba}_{0.6} \mathrm{Y}_{1.2}$ $\mathrm{Sm}_{0.2} \mathrm{Sn}_{1.8} \mathrm{Cr}_{0.2} \mathrm{O}_{7}$ catalyst in $\mathrm{CO}_{2}$-containing atmosphere is an attractive advantage. It was also observed that the activity of $\mathrm{Ba}_{0.6} \mathrm{Y}_{1.2} \mathrm{Sm}_{0.2} \mathrm{Sn}_{1.8} \mathrm{Cr}_{0.2} \mathrm{O}_{7}$ for $\mathrm{NO}$ absorption was not decreased despite a $\mathrm{CO}_{2}$ content of $5 \%$, and this activity remained constant even when the time of exposure to the lean-burn mixture was longer than $4 \mathrm{~h}$. This proves that if barium is incorporated into a well-defined crystallographic structure, it is protected against deactivation by carbonation. Moreover, it has been reported that if barium has a strong bond with aluminium or tin, it will be protected against carbonation. ${ }^{22)}$

An FT-IR spectrum of the $\mathrm{Ba}_{0.6} \mathrm{Y}_{1.2} \mathrm{Sm}_{0.2} \mathrm{Sn}_{1.8} \mathrm{Cr}_{0.2} \mathrm{O}_{7}$ sample was recorded before and after exposure to $\mathrm{NO}$ in $\mathrm{O}_{2}$ by the $\mathrm{KBr}$ method. The spectrum after NO sorption clearly indicated the appearance of the absorption band at around $1385 \mathrm{~cm}^{-1}$ (Fig. 8). The sharp band is attributed to the nitrate ion, $\mathrm{NO}_{3}{ }^{-}$, on the solid. Therefore, the removal of $\mathrm{NO}$ by this system proceeds by oxidation of $\mathrm{NO}$ to $\mathrm{NO}_{3}$ - ions on the solid surface. The IR band for the $\mathrm{Ba}_{0.6} \mathrm{Y}_{1.2} \mathrm{Sm}_{0.2} \mathrm{Sn}_{1.8}$ $\mathrm{Cr}_{0.2} \mathrm{O}_{7}$ oxide before the absorption treatment after heating at $475^{\circ} \mathrm{C}$ exhibited a small band at $1385 \mathrm{~cm}^{-1}$. This band is assigned to the $v_{3}$ stretching band of the $\mathrm{NO}_{3}-$ ion which ex- 

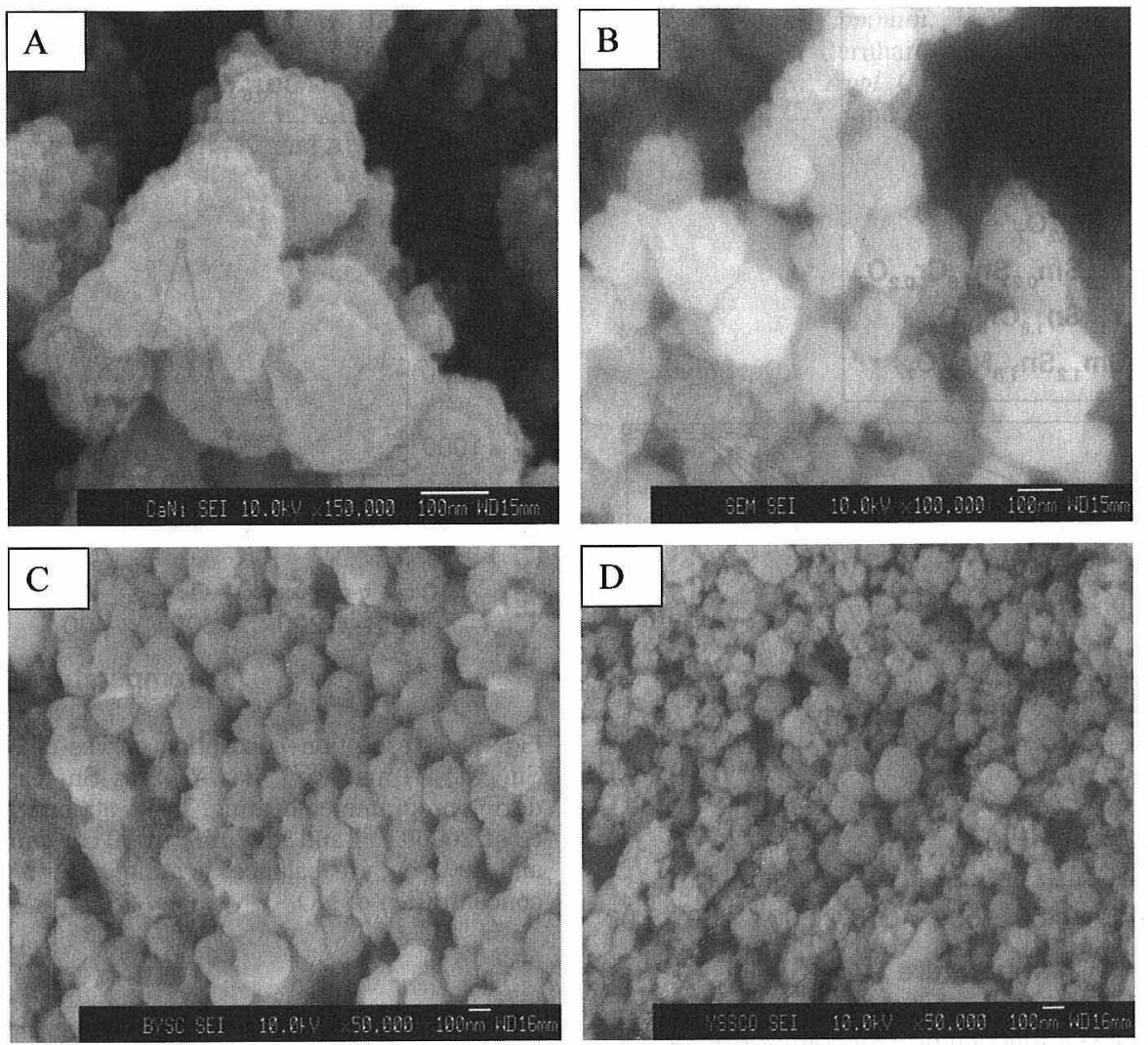

Fig. 4. Typical SEM micrograph of (A) $\mathrm{Ca}_{0.8} \mathrm{Sm}_{1.2} \mathrm{Sn}_{1.8} \mathrm{Ni}_{0.2} \mathrm{O}_{7}$, (B) $\mathrm{Ba}_{0.6} \mathrm{Y}_{1.2} \mathrm{Sm}_{0.2} \mathrm{Sn}_{1.8} \mathrm{Cr}_{0.2} \mathrm{O}_{7}$ (high magnification), (C) $\mathrm{Ba}_{0.6} \mathrm{Y}_{1.2} \mathrm{Sm}_{0.2}$ $\mathrm{Sn}_{1.8} \mathrm{Cr}_{0.2} \mathrm{O}_{7}$ (low magnification) and (D) $\mathrm{Y}_{2} \mathrm{Sn}_{1.8} \mathrm{Cr}_{0.2} \mathrm{O}_{7}$ pyrochlore powders.
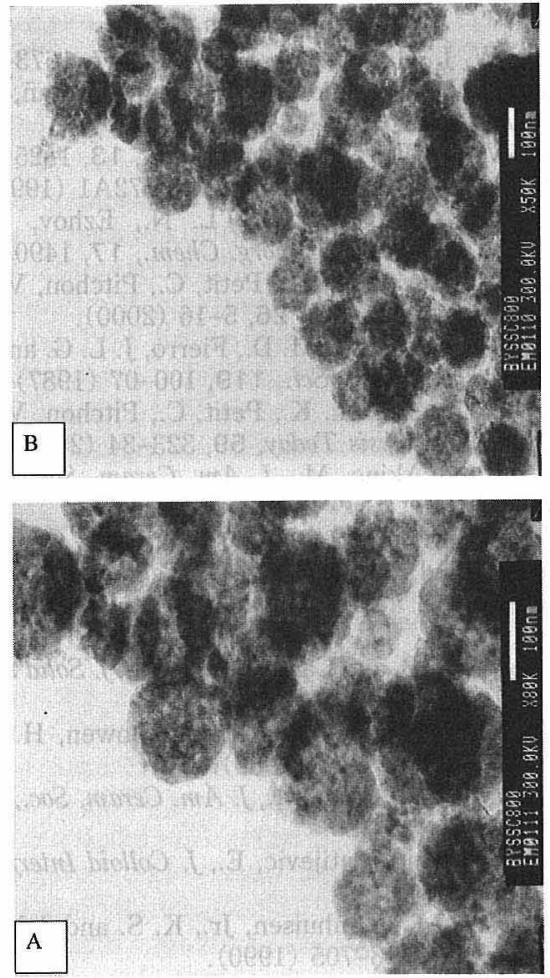

Fig. 5. TEM micrographs for the synthesized (A) $\mathrm{Ba}_{0.6} \mathrm{Y}_{1.2} \mathrm{Sm}_{0.2}$ $\mathrm{Sn}_{1.8} \mathrm{Cr}_{0.2} \mathrm{O}_{7}$ (high magnification) and (B) $\mathrm{Ba}_{0.6} \mathrm{Y}_{1.2} \mathrm{Sm}_{0.2} \mathrm{Sn}_{1.8} \mathrm{Cr}_{0.2} \mathrm{O}_{7}$ (low magnification) at $190^{\circ} \mathrm{C}, \mathrm{pH} 10.3$ under hydrothermal conditions. hibits the strongest peak in most nitrates, ${ }^{23)}$ whereas other bending bands in the low-wave-number region could not be clearly observed due to the overlap with the band of the oxide. Residual nitrate ions seem to be present even after heat treatment at $475^{\circ} \mathrm{C}$. The intensity of this band increased after the absorption of NO for $10 \mathrm{~h}$.

The effect of the contact time $(W / F)$ was also investigated, where $W$ is the weight of the $\mathrm{Ba}_{0.6} \mathrm{Y}_{1.2} \mathrm{Sm}_{0.2} \mathrm{Sn}_{1.8} \mathrm{Cr}_{0.2} \mathrm{O}_{7}$ oxide and $F$ is the total flow rate. NO removal was almost constant for contact times of $1.0,0.5$, and $0.24 \mathrm{~g} \cdot \mathrm{s} \cdot \mathrm{cm}^{-3}$ at the start of absorption, whereas it decreased sharply in the case of $W / F=0.12 \mathrm{~g} \cdot \mathrm{s} \cdot \mathrm{cm}^{-3}$. Since a high flow rate led to a rapid saturation of absorption, the total absorption capacity was unchanged with $W / F$. The contact time and NO concentration did not affect the overall absorption capacity under the present experimental conditions, and the initial NO removal was high in every case. Therefore, the absorption was regarded as being very rapid. Such rapid absorption is favorable for practical applications of the NO-removal system

\section{Conclusions}

The preparation of uniform A- and B-site-substituted yttrium tin oxide with a phase-pure pyrochlore structure at temperatures as low as $200^{\circ} \mathrm{C}$ has been demonstrated. For the formation of pyrochlore, the $\mathrm{pH}$ of the initial hydrothermal reaction medium must be above 10 . The methodology presented in this work provides a simple method for preparing spherical pyrochlore oxide powder with a high surface area. Pyrochlore compounds have been developed as potential catalysts for $\mathrm{NO}_{x}$ traps and have revealed interesting properties because their trapping capacity is high and the temperature of both absorption and desorption are in a 


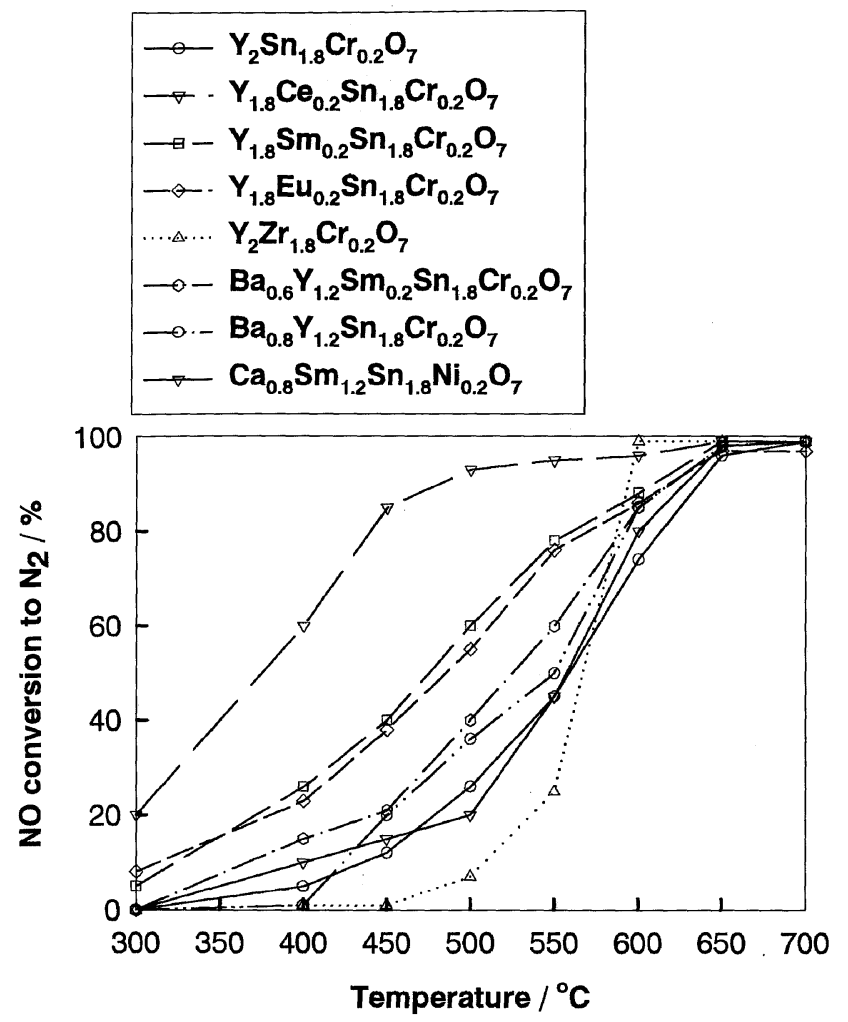

Fig. 6. NO conversion as a function of temperature over several pyrochlore oxide catalysts. The reaction was run at a space velocity of $20000 \mathrm{~h}^{-1}$ and flow rate of $50 \mathrm{~cm}^{3} \mathrm{~min}^{-1}$ with $1000 \mathrm{ppm} \mathrm{NO}$, $2000 \mathrm{ppm} \mathrm{CH}_{4}$, He balance.

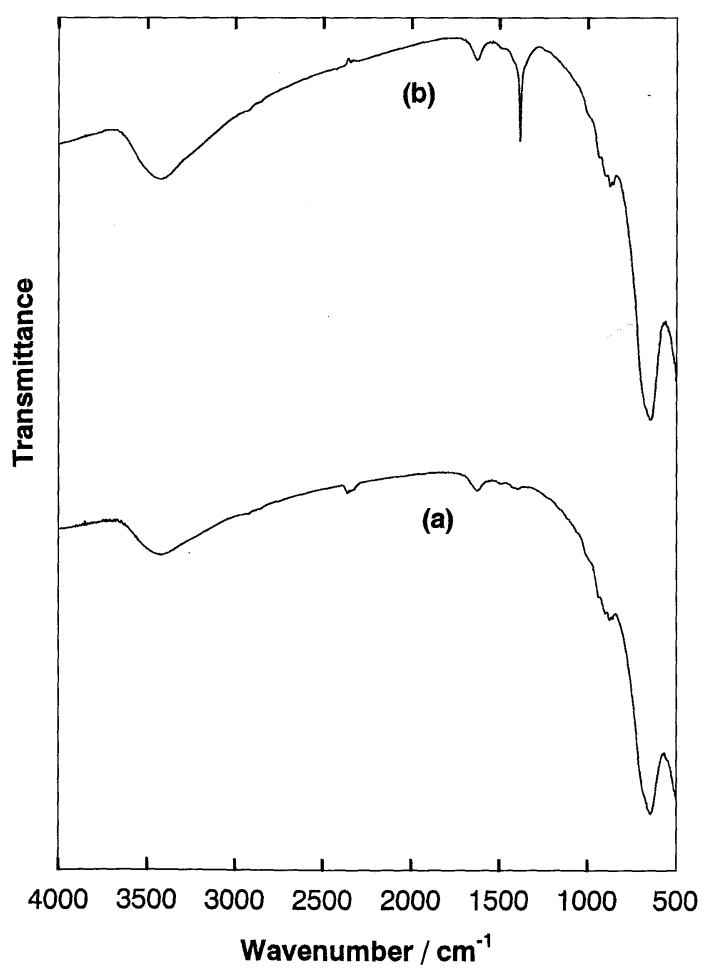

Fig. 8. FT-IR spectra of $\mathrm{Ba}_{0.6} \mathrm{Y}_{1.2} \mathrm{Sm}_{0.2} \mathrm{Sn}_{1.8} \mathrm{Cr}_{0.2} \mathrm{O}_{7}$ oxide (a) after heating in air at $475^{\circ} \mathrm{C}$ and (b) after absorption of $\mathrm{NO}$ at $200^{\circ} \mathrm{C}$.

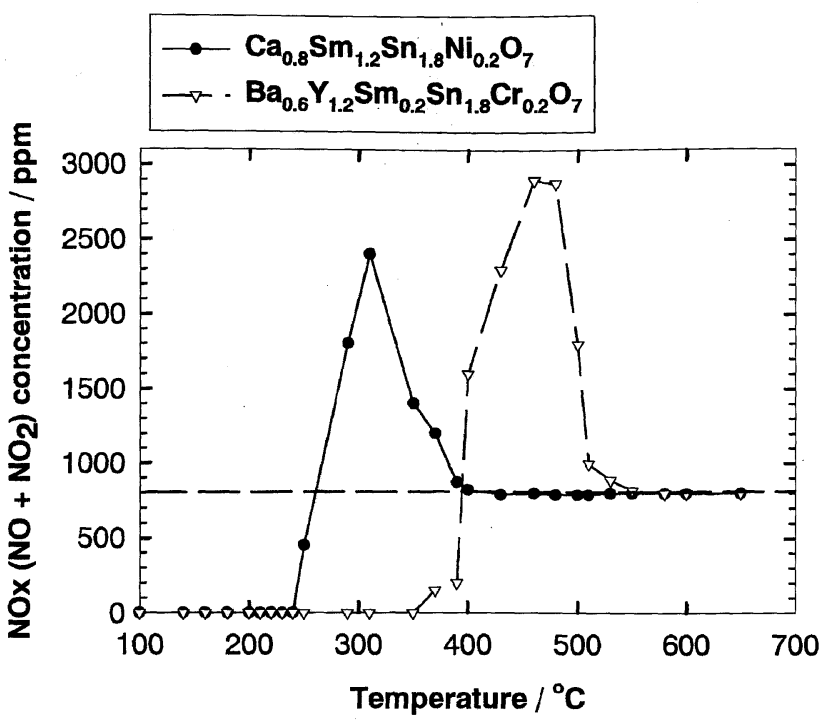

Fig. 7. Absorption-desorption curves of $\mathrm{NO}_{x}$ by $(\bullet) \mathrm{Ca}_{0.8} \mathrm{Sm}_{12}$ $\mathrm{Sn}_{1.8} \mathrm{Ni}_{0.2} \mathrm{O}_{7}$ and $(\nabla) \mathrm{Ba}_{0.6} \mathrm{Y}_{1.2} \mathrm{Sm}_{0.2} \mathrm{Sn}_{1.8} \mathrm{Cr}_{0.2} \mathrm{O}_{7}$ pyrochlore oxide during programmed heating. The reaction was run at a space velocity of $20000 \mathrm{~h}^{-1}$ and flow rate of $50 \mathrm{~cm}^{3} \mathrm{~min}^{-1}$ with $800 \mathrm{ppm} \mathrm{NO}$, and $10 \% \mathrm{O}_{2}$, He balance, heating rate $=5^{\circ} \mathrm{C} \min ^{-1}$, (--) initial concentration of NO.

range relevant for industrial applications.

Acknowledgments This work has been supported by METI, Japan, as part of the Synergy Ceramics Project. The work is also partly supported by NEDO. The authors are members of the Joint Research Consortium of Synergy Ceramics.

\section{References}

1) Dawson, W. J., Am. Ceram. Soc. Bull., 67, 1673-78 (1988).

2) Belyaev, I. N., Sholokhovich, M. L. and Kkhañ, N., Russ. J. Inorg. Chem., 23, 1112-13 (1978).

3) Pitchon, V. and Fritz, A., Appl. Catal., 13, 1-25 (1997).

4) Toyota Patent European Patent 573 672A1 (1992).

5) Belyaev, I. N., Aveàyanova, L. N., Ezhov, V. M. and Balashov, D. V., Russ. J. Inorg. Chem., 17, 1490 (1972).

6) Hodjati, S., Vaezzadeh, K., Petit, C., Pitchon, V. and Kiennemann, A., Appl. Catal., 26, 5-16 (2000).

7) Pena, M. A., Tascon, J. M. D., Fierro, J. L. G. and Gonzalez, T. L., J. Colloid Interf. Sci., 119, 100-07 (1987).

8) Hodjati, S., Vaezzadeh, K., Petit, C., Pitchon, V. and Kiennemann, A., Catalysis Today, 59, 323-34 (2000).

9) Ünalo, Ö. and Akinc, M., J. Am. Ceram. Soc., 79, 805-08 (1996).

10) Osada, Y., Koike, S., Fukushima, T., Ogasawara, S., Shikada, T. and Ikariya, T., Appl. Catal., 59, 59-65 (1990).

11) Fokema, M. D. and Ying, J. Y., J. Catalysis, 192, 54-63 (2000).

12) Goodenough, J. B. and Castellono, R. N., J. Solid State Chem., 44, 108-12 (1982).

13) Riman, R. E., Landham, R. R. and Bowen, H. K., J. Am. Ceram. Soc., 72, 821-26 (1989).

14) Celikkaya, A. and Akinc, M., J. Am. Ceram. Soc., 73, 245-50 (1990).

15) Nishikawa, S. and Matijevic, E., J. Colloid Interf. Sci., 165, 141-47 (1994).

16) Denkewics, R. P., Tenhuisen, Jr., K. S. and Adair, J. H., J. Mater. Res., 5, 2698-705 (1990).

17) Moon, J., Awano, M. and Maeda, K., J. Am. Ceram. Soc., 84, 2531-36 (2001).

18) Wuensch, B. J., Eberman, K. W., Heremans, C., Ku, M. E., Onnerud, P., Yeo, E. M. E., Haile, S. M., Stalick, J. K and Jorgensen., J. D., Solid State Ionics, 129, 111-33 (2000). 
19) Teraoka, Y., Torigoshi, K., Yamaguchi, H., Ikeda, T. and Kagawa, S., J. Mole. Catal., A 155, 73-80 (2000).

20) Tabata, K., Fukui, H., Kohiki, S., Mizuno, N. and Misono, M., Chem. Lett., 5, 799-802 (1988).

21) Machida, M., Yasuoka, K., Eguchi, K. and Arai, H., J. Chem.
Soc.,: Chem. Commun., 1165-66 (1990).

22) Hodjati, S., Bernhardt, P., Petit, C., Pitchon, V. and Kiennemann, A., Appl. Catal., 19, 221-32 (1998).

23) Addison, C. C. and Gatehouse, B. M., J. Chem. Soc., 613-16 (1960). 